\title{
EFISIENSI KINERJA BAZNAS BOGOR DAN SUKABUMI: PENDEKATAN DATA ENVELOPMENT ANALYSIS
}

\author{
Siti Nurhasanah dan Deni Lubis \\ Departemen Ilmu Ekonomi Syariah Institut Pertanian Bogor \\ Email: sitinurhasanah2304@gmail.com
}

\begin{abstract}
This study aims to know how performance efficiency BAZNAS in Bogor city, Bogor district, and Sukabumi district, and recommends things need BAZNAS have not been efficient can reach 100 percent efficiency level. This research using Data Envelopment Analysis (DEA) method, with intermediation approach and production approach. The input and output intermediation approach are collected funds, operational costs, and channeled funds. The input and output of production approach are operational costs, socialization costs, collected funds, and channeled funds. The result of this study show that with intermediate approach BAZNAS has descresed efficiency. Calculation of production approach indicates that BAZNAS has increased efficiency value. Badan Amil Zakat Nasional Sukabumi district has obtained efficiency 100 percent in the both approaches. Badan Amil Zakat Nasional have not been efficient can diminished operational cost and socialization cost, then increased collected funds and channeled funds.
\end{abstract}

Keywords: $\quad$ Data Envelopment Analysis (DEA), intermediation approach, production approach.

\section{PENDAHULUAN}

Kemiskinan merupakan permasalahan yang dihadapi Pemerintah Indonesia. Islam menawarkan solusi dalam menghadapi masalah tersebut dengan instrumen zakat. Zakat merupakan rukun Islam ketiga yang menjadi pilar penting dalam ajaran Islam. Oleh sebab itu, zakat wajib dilaksanakan oleh setiap muslim yang telah memenuhi syarat. Zakat merupakan kegiatan untuk mentransfer dana dari pihak yang berkecukupan, kepada pihak yang membutuhkan. Banyak manfaat yang diperoleh dari zakat, salah satunya adalah distribusi pendapatan. Distribusi pendapatan antara muzaki dan mustahiq diharapkan dapat mengurangi jumlah kemiskinan.

Berdasarkan penelitian Beik (2009) terhadap 50 mustahiq penerima zakat Dompet Dhuafa Republika, menunjukkan zakat dapat mengurangi jumlah keluarga miskin dari 84 persen menjadi 74 persen. Zakat mampu mengurangi kesenjangan kemiskinan dan kesenjangan pendapatan. Zakat juga mampu mengurangi tingkat keparahan kemiskinan dengan adanya penurunan nilai Indeks Sen. Penelitian ini membuktikan bahwa instrumen zakat memiliki manfaat yang sangat besar dalam perekonomian.

Dana zakat yang terhimpun setiap tahunnya mengalami peningkatan. Outlook Zakat Indonesia 2017 yang diterbitkan oleh Pusat Kajian Strategis Badan Amil Zakat Nasional (PUSKASBAZNAS) menunjukkan, setiap 
tahunnya dana zakat yang terhimpun mengalami peningkatan. Peningkatan tersebut disebabkan oleh meningkatnya partisipasi lembaga atau perusahaan untuk berzakat. Pengelolaan zakat yang optimal akan berdampak pada menurunnya jumlah kemiskinan. Dana zakat yang terhimpun setiap tahunnya mengalami peningkatan, akan tetapi jumlah penduduk miskin masih berfluktuasi. Hal tersebut menunjukkan bahwa pengelolaan dana zakat yang dilakukan belum optimal.

Menurut Sudibyo (2016) potensi zakat di Indonesia pada tahun 2015 mencapai 286 triliun rupiah. Realisasinya zakat yang terhimpun pada tahun 2015 hanya 3.7 triliun. Terdapat gap antara potensi dengan jumlah dana zakat yang terhimpun. Gap tersebut merupakan tantangan bagi organisasi pengelola zakat dalam meningkatkan kinerjanya. Organisasi pengelola zakat bertindak sebagai amil yang bertugas menghimpun dan menyalurkan dana zakat. Efisiensi biaya dalam penghimpunan dan penyaluran dana zakat perlu dilakukan, sehingga manfaat zakat dapat dirasakan oleh lebih banyak mustahiq.

Berdasarkan penelitian Cahyono (2015), skor efisiensi BAZNAS mengalami tren yang berfluktuasi. Input yang digunakan dalam penelitian tersebut yaitu biaya operasional dan biaya personalia. Output yang digunakan yaitu dana yang terhimpun dan dana yang tersalurkan. Pengukuran efisiensi BAZNAS dilakukan dari tahun 2007-2013. Berikut adalah grafik skor efisiensi yang diperoleh BAZNAS.

Grafik 1. Skor efisiensi BAZNAS Pusat

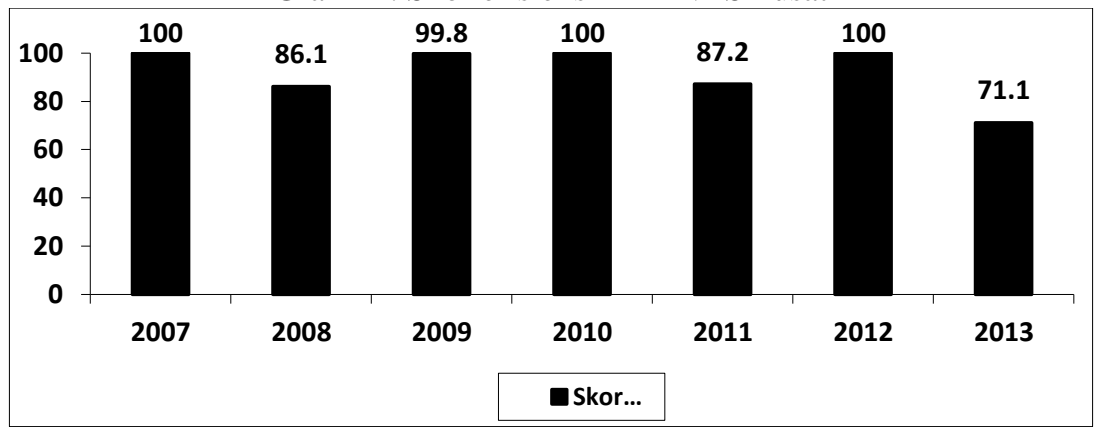

Sumber: Cahyono (2015)

Grafik 1 menunjukkan skor efisiensi BAZNAS berdasarkan penelitian Cahyono (2015). Badan Amil Zakat Nasional (BAZNAS) memperoleh skor efisiensi 100 persen pada tahun 2007, 2010 dan 2012. Skor efisiensi terkecil diperoleh pada tahun 2013 sebesar 71.1 persen. Grafik tersebut menunjukkan lebih banyak skor yang inefisien dibandingkan dengan skor yang efisien. Oleh sebab itu, BAZNAS perlu meningkatkan efisiensi biaya dalam menghimpun dan menyalurkan dana zakat, serta mengoptimalkan penghimpunan dan penyaluran dana zakat.

Jumlah penduduk miskin terbesar tingkat kota dan kabupaten di Jawa Barat yaitu Kabupaten Bogor. Pada tahun 2014 jumlah penduduk miskin 
Kabupaten Bogor sebesar 479.1 ribu orang atau 8.9 persen dari total jumlah penduduk. Jumlah penduduk miskin tahun 2014 di Kabupaten Sukabumi termasuk tinggi, sebanyak 213.6 ribu orang atau 8.8 persen penduduk di Kabupaten Sukabumi tergolong penduduk miskin. Kota Bogor memiliki jumlah penduduk yang lebih sedikit, jika dibandingkan dengan Kabupaten Bogor dan Kabupaten Sukabumi. Oleh sebab itu, jumlah penduduk miskin di Kota Bogor relatif lebih sedikit dibandingkan dengan Kabupaten Bogor dan Kabupaten Sukabumi. Jumlah penduduk miskin di Kota Bogor pada tahun 2014 sebanyak 80.1 ribu orang atau 7.7 persen dari jumlah penduduk Kota Bogor.

Penelitian terkait efisiensi Organisasi Pengelola zakat dengan menggunakan metode DEA telah banyak diterapkan. Lestari (2015) meneliti efisiensi kinerja Badan Amil Zakat Daerah (BAZDA) dengan metode Data Envelopment Analysis (DEA). Objek yang diteliti yaitu laporan keuangan BAZDA Kabupaten Lombok Timur pada periode 2012-2014 dengan pendekatan intermediasi. Hasil penelitian menunjukkan pada tahun 20122014 Kabupaten Lombok Timur mengalami efisiensi sebesar 100 persen.

Kemudian Akbar (2009) meneliti efisiensi Organisasi Pengelola Zakat Nasional menggunakan metode Data Analysis Envelopment (DEA) dengan pendekatan produksi. Objek yang diteliti adalah laporan keuangan dari 9 OPZ pada periode 2005-2007. Hasil penelitian menunjukkan tahun 2005 lebih efisien dibandingkan dengan dua tahun setelahnya. Pengukuran efisiensi teknis menunjukkan, Dompet Dhuafa merupakan OPZ yang paling efisien dari tahun ke tahun selama periode 2005-2007. Lembaga Amil Zakat PKPU dan BRI efisien 100 persen pada tahun 2005 dan 2006. Badan Amil Zakat Nasional efisien 100 persen pada tahun 2005.

Rusydiana dan Al-Farisi (2016) meneliti efisiensi tiga organisasi pengelola zakat, yaitu BAZNAS, PKPU, dan Rumah Zakat pada periode 2007-2014. Metode yang digunakan yaitu Data Envelopment Analysis (DEA) dengan pendekatan produksi. Hasil penelitian menunjukkan, terdapat 12 DMU yang telah efisien dan enam DMU yang belum efisien. Faktor utama yang menyebabkan inefisiensi adalah distribusi dana zakat yang belum optimal.

Al-Parisi (2017) meneliti tingkat efisiensi dan produktivitas lembaga zakat di Indonesia. Lembaga zakat yang diteliti yaitu BAZNAS, YBM BRI, PKPU, Dompet Dhuafa, dan Rumah Zakat. Metode yang digunakan yaitu Data Envelopment Analysis (DEA). Hasil dari penelitian menunjukkan terdapat lima DMU yang efisien dan 22 DMU yang belum efisien. Penyebab utama inefisiensi adalah dana yang tersalurkan belum optimal.

Kemudian yang membedakan penelitian ini dengan penelitian yang sebelumnya adalah objek dan tahun yang diteliti. Penelitian ini lebih difokuskan pada BAZNAS tingkat kota dan kabupaten yaitu BAZNAS Kota dan Kabupaten Bogor, serta BAZNAS Kabupaten Sukabumi. Pemilihan BAZNAS tersebut didasarkan pada besarnya potensi zakat yang ada. Mayoritas penduduk di Kota Kabupaten Bogor dan Kabupaten Sukabumi beragama Islam, sehingga potensi zakat yang ada relatif besar. Potensi zakat 
Kota Bogor berdasarkan pendekatan tiga sektor dalam penelitian Santika (2015) mencapai 462402202437 rupiah. Kabupaten Bogor merupakan kabupaten dengan jumlah penduduk terbanyak tingkat kota kabupaten di Jawa Barat, sehingga potensi zakat yang ada juga besar. Penduduk di Kabupaten Sukabumi juga tergolong besar, jumlah penduduk lebih dari dua juta jiwa pada tahun 2015, sehingga potensi dana zakat yang ada juga besar.

Potensi dana zakat yang ada perlu digali, agar dana zakat dapat terhimpun secara optimal. Dana zakat yang terkumpul diharapkan dapat mengurangi jumlah kemiskinan, mengingat di Kota Kabupaten Bogor dan Kabupaten Sukabumi jumlah penduduk miskinnya relatif tinggi. Efisiensi biaya dalam pengelolaan zakat perlu dilakukan, agar dana zakat yang terkumpul dapat membantu pemerintah dalam mengurangi kemiskinan.

\section{KAJIAN TEORI}

\subsection{ZAKAT}

Zakat merupakan kewajiban yang harus dilaksanakan oleh umat Islam. Hafidhuddin (2002) mengemukakan pengertian zakat, secara bahasa zakat berarti suci, tumbuh, berkembang, dan penuh keberkahan. Zakat dapat berarti juga membersihkan atau mensucikan, yaitu membersihkan hati pemilik harta dari sifat kikir. Pengertian zakat secara terminologi adalah mengeluarkan sebagian harta dengan syarat tertentu untuk diberikan kepada pihak tertentu yang memenuhi persyaratan tertentu.

\subsection{KONSEP DAN PENGERTIAN EFISIENSI}

Menurut KBBI efisiensi adalah ketepatan usaha tanpa membuang waktu dan biaya dengan hasil yang optimal. Efisiensi membandingkan input yang digunakan dengan ouput yang dihasilkan. Efisiensi didefinisikan melakukan sesuatu dengan benar, berkaitan dengan cara bagaimana perusahaan mencapai tujuannya. Efisiensi juga didefinisikan sebagai kemampuan suatu organisasi untuk memaksimalkan output dalam jumlah tertentu atau meminimalkan pengunaan input.

Efisiensi dibagi menjadi dua komponen yaitu efisiensi teknis dan efisiensi alokatif. Efisiensi teknis yaitu kemampuan perusahaan mengelola input yang tersedia agar menghasilkan output yang optimal. Efisiensi alokatif yaitu kemampuan perusahaan mengoptimalkan penggunaan inputnya dengan struktur harga dari masing-masing input. Gabungan dari kedua efisiensi ini menghasilkan efisiensi ekonomi. Pengukuran efisiensi dapat dilakukan dengan dua pendekatan, yaitu:

1. Input Oriented Measure

Pengukuran berorientasi input menghitung berapa banyak input yang dapat dikurangi tanpa mengubah jumlah output yang dihasilkan. Perhitungan ini menekankan pada pengurangan input yang digunakan dari pada peningkatan output. 


\section{Output Oriented Measure}

Pengukuran berorientasi output yaitu menghitung berbagai macam output yang dapat ditingkatkan tanpa mengubah jumlah input yang digunakan. Perhitungan ini lebih menekankan bagaimana cara meningkatkan jumlah output dibandingkan mengurangi jumlah input yang digunakan.

Konsep pendekatan yang mendefinisikan hubungan input dan output dalam membentuk sebuah model efisiensi berdasarkan penelitian Hadad et al (2003) didefinisikan melalui tiga pendekatan. Penelitian sebelumnya juga menggunakan pendekatan untuk mengukur efisiensi organisasi pengelola zakat.

1. Pendekatan Produksi

Dalam perbankkan pendekatan ini mendefinisikan lembaga finansial sebagai produsen dari akun deposit dan kredit. Akun deposit dan kredit digunakan sebagai variabel output. Input yang digunakan adalah jumlah tenaga kerja, pengeluaran modal, dan aset tetap lainnya. Pendekatan ini mendefinikan organisasi pengelola zakat sebagai produsen dari dana terhimpun dan dana tersalurkan. Oleh karena itu, output dari pendekatan ini adalah dana terhimpun dan dana tersalurkan. Inputnya menggunakan variabel biaya operasional, biaya sosialisasi, dan biaya personalia.

\section{Pendekatan Intermediasi}

Pendekatan ini mendefiniskan lembaga keuangan sebagai lembaga mediator untuk menyalurkan dana. Inputnya biaya tenaga kerja, modal, dan pembayaran bunga deposito. Outputnya kredit pinjaman dan investasi finansial. Input yang digunakan organisasi pengelola zakat yaitu dana terhimpun, biaya personalia, dan biaya operasional. Ouput yang digunakan yaitu dana tersalurkan, aktiva tetap, dan aktiva lancar.

3. Pendekatan Aset

Mendefinisikan lembaga finansial sebagai lembaga kredit pinjaman. Output pendekatan ini diukur dalam bentuk aset.

Penelitian ini menggunakan pendekatan produksi dan pendekatan intermediasi. Pendekatan aset tidak digunakan karena BAZNAS merupakan lembaga mediator yang menyalurkan dana zakat kepada mustahiq, bukan lembaga yang menyalurkan dananya kedalam bentuk aset.

Efisiensi dalam Islam adalah upaya yang dilakukan untuk memperoleh hasil yang optimal. Hasil yang optimal hanya dapat diperoleh dengan usaha yang optimal. Usaha yang dilakukan menentukan hasil yang diperoleh. Dalam Al-Quran sendiri konsep efisiensi disebutkan dalam Qs. Al isra ayat 27.

"Sesungguhnya orang-orang yang pemboros itu adalah saudara syaitan, dan syaitan itu sangat ingkar kepada tuhannya." 
Ayat tersebut sangat menganjurkan manusia untuk tidak berperilaku boros, karena perilaku boros merupakan perbuatan syaitan. Menekan biaya sebesar-besarnya untuk mendapat hasil sebanyak-banyaknya tidak dibenarkan. Akan tetapi, tidak dibenarkan juga mengeluarkan biaya sebanyak-banyaknya secara berlebihan.

Menurut Rahmayanti (2014) kinerja adalah sebuah sebuah konsep multidimensi yang dapat berupa waktu, kualitas, inovasi, efektivitas, dan efisiensi. Mengukur kinerja organisasi nirlaba seperti BAZNAS dapat menggunakan efisiensi. Pengukuran kinerja dapat digunakan untuk melakukan perbaikan, peningkatan kualitas pelayanan, dan menentukan keputusan yang tepat dalam mengambil kebijakan.

\subsection{BADAN AMIL ZAKAT NASIONAL}

Organisasi pengelola zakat adalah lembaga intermediasi yang bersifat nirlaba. Dalam Undang-undang Nomor 23 tahun 2011 Organisasi Pengelola Zakat (OPZ) di Indonesia terdiri dari Badan Amil Zakat Nasional (BAZNAS) dan Lembaga Amil Zakat (LAZ). Badan Amil Zakat Nasional merupakan lembaga pengelola zakat yang didirikan oleh pemerintah. Lembaga Amil Zakat merupakan lembaga yang dibentuk oleh masyarakat. Lembaga Amil Zakat bertugas membantu BAZNAS dalam melaksanakan pengumpulan, pendistribusian dan pendayagunaan zakat. Landasan pengelolaan zakat terdapat dalam Al Quran surat At-Taubah ayat 103, yang artinya:

"Ambillah zakat dari harta mereka, guna membersihkan dan mensucikan mereka, dan berdoalah untuk mereka. Sesungguhnya doamu itu (menumbuhkan) ketentraman jiwa bagi mereka. Allah Maha mendengar, Maha mengetahui."

Badan Amil Zakat Nasional terdiri dari Badan Amil Zakat Nasional (BAZNAS) yang berkedudukan di Ibu kota negara. Badan Amil Zakat Nasional dibentuk oleh presiden atas usul menteri. Badan Amil Zakat Nasional provinsi berkedudukan di provinsi, dibentuk oleh menteri atas usul gubernur setelah mendapat pertimbangan dari BAZNAS. Badan Amil Zakat Nasional kota/kabupaten dibentuk oleh menteri atas usulan Bupati/Walikota setelah mendapat pertimbangan BAZNAS. Dalam melaksanakan tugasnya BAZNAS provinsi, kota, dan kabupaten berhak membentuk Unit Pengumpul Zakat (UPZ).

Menurut Qardhawi (2011) Organisasi pengelola zakat merupakan lembaga yang bertindak selaku amil. Amil merupakan pegawai yang berhak menerima upah sesuai dengan pekerjaannya. Menurut Imam Syafi'i amilin diberi zakat sebesar bagian kelompok lainnya. Imam Syafi'i berpendapat semua asnaf memperoleh bagian yang sama sebesar 12.5 persen. Jika upah yang berhak diterima amil lebih besar, maka haruslah diambil dari harta diluar dana zakat. Menurut Jumhur pendistribusian dana zakat tidak harus dilakukan secara merata. Akan tetapi, pendapat Imam Syafi'i dianggap relevan untuk memelihara kepentingan fakir miskin dan mustahiq lain, sehingga amilin harus berlaku ekonomis dalam kinerjanya. 


\subsection{DATA ENVELOPMENT ANALYSIS}

Data Envelopment Analysis (DEA) merupakan metode yang digunakan untuk mengukur tingkat efisiensi dari suatu organisasi atau unit kegiatan ekonomi. Data Envelopment Analysis merupakan model program yang bisa mencakup banyak output dan banyak input. Metode DEA didesain untuk mengukur efisiensi relatif sebuah organisasi yang disebut Decision Making Unit (DMU). Efisiensi relatif adalah membandingkan efisiensi DMU dengan DMU lain dalam sampel. Decision making unit yang dibandingkan menggunakan input dan output yang sama. Efisiensi relatif dari unit kegiatan ekonomi dalam DEA didefinisikan sebagai perbandingan dari total output dibagi total input (total weighted output / total weighted input). Inti DEA adalah menentukan bobot atau weight input dan output dari unit kegiatan ekonomi. Bobot dalam DEA memiliki sifat tidak bernilai negatif.

Terdapat dua model yang biasa digunakan dalam DEA untuk mengukur efisiensi, yaitu Charnes Cooper dan Rhodes (CCR) dan Banker Charnes dan Cooper (BCC). Model CCR diperkenalkan pertama kali oleh Charnes, Cooper, dan Rhodes pada tahun 1978. Model tersebut mengasumsikan adanya Constant Return to Scale (CRS), model CCR disebut juga model CRS. Constant return to scale yaitu perubahan pada semua tingkat input secara proposional akan menghasilkan perubahan yang sama pada tingkat outputnya. Contohnya penambahan satu input akan meningkatkan satu output.

Model BCC diperkenalkan pada tahun 1984 oleh Banker, Charnes, dan Cooper untuk memperluas model CCR. Model BCC mengasumsikan adanya Variabel Return to Scale (VRS). Variable return to scale yaitu jika ada penambahan input sebesar $n$ kali, maka output tidak meningkat sebesar $n$ kali dapat lebih besar atau lebih kecil. Kondisi dimana organisasi dapat menghasilkan output yang lebih besar disebut Increasing Return to Scale (IRS). Kondisi dimana output yang dihasilkan lebih kecil dari n kali disebut Decreasing Return to Scale (DRS). Perbedaan antara nilai CRS dan VRS menghasilkan efisiensi skala.

Metode yang digunakan dalam mengukur efisiensi dikelompokan menjadi dua, yaitu pendekatan parametrik dan pendekatan non-parametrik. Pendekatan parametrik yaitu pendekatan statistik yang mempertimbangkan jenis sebaran atau distribusi data. Metode yang dapat digunakan untuk pendekatan non-parametrik yaitu Data Envelopment Analysis (DEA). Data Envelopment Analysis merupakan pendekatan non-parametrik yang modelnya tidak menetapkan syarat-syarat tertentu. Penggunaan DEA lebih sederhana dan tidak dibutuhkan spesifikasi bentuk fungsi. Dalam memaksimalkan nilai efisiensi, setiap unit kegiatan ekonomi dapat memilih antara produksi output secara maksimum atau meminimalkan penggunaan input. 


\section{METODE PENELITIAN}

Data yang digunakan dalam penelitian ini adalah data sekunder. Data diperoleh langsung dari BAZNAS Kota Bogor, Kabupaten Bogor, dan Kabupaten Sukabumi. Data tersebut berupa laporan keuangan pada periode 2015 dan 2016. Sumber data diperoleh selain dari BAZNAS secara langsung juga diperoleh dari literatur-literatur lain. Literatur tersebut diantaranya jurnal, sripsi, buku, dan website.

Efisiensi BAZNAS kota kabupaten diukur menggunakan penelitian kuantitatif dengan pendekatan non-parametrik. Metode yang digunakan yaitu Data Envelopment Analysis. Pengolahan data dilakukan dengan menggunakan software DEAP version 2.1 dan Microsoft Excel. Objek dalam penelitian ini adalah laporan keuangan BAZNAS Kota Bogor, Kabupaten Bogor, dan Kabupaten Sukabumi pada periode 2015 dan 2016.

Variabel input yang digunakan dalam pendekatan intermediasi yaitu dana terhimpun dan biaya operasional. Variabel output yang digunakan dalam pendekatan intermediasi yaitu dana tersalurkan. Variabel input yang digunakan dalam pendekatan produksi yaitu biaya operasional dan biaya sosialisasi. Variabel output yang digunakan dalam pendekatan produksi yaitu dana terhimpun dan dana tersalurkan.

\section{HASIL DAN PEMBAHASAN}

\subsection{HASIL PENGUKURAN EFISIENSI}

Efisiensi adalah salah satu indikator keberhasilan perusahaan atau organisasi. Usaha meningkatkan efisiensi dikaitkan dengan biaya yang lebih kecil untuk memperoleh hasil tertentu, atau dengan biaya tertentu untuk memperoleh hasil yang lebih banyak. Mengukur efisiensi kinerja BAZNAS dilakukan dengan menggunakan metode Data Envelopment Analysis. DEA mengukur efisiensi secara relatif bukan absolut. DEA mengukur efisiensi dengan membandingkan input dan output yang digunakan. Model yang digunakan yaitu constant return to scale dan variable return to scale. Perhitungan efisien BAZNAS menggunakan input dan output oriented. Efisiensi yang diukur dalam penelitian ini adalah efisiensi teknis. Pendekatan yang digunakan yaitu pendekatan intermediasi dan pendekatan produksi.

\section{a. Pendekatan Intermediasi}

Pendekatan intermediasi yaitu pendekatan yang mengasumsikan BAZNAS sebagai lembaga mediator. Badan Amil Zakat Nasional bertindak sebagai lembaga yang menyalurkan dana terhimpun kepada mustahiq. Model yang digunakan dalam perhitungan yaitu constant return to scale dan variable return to scale, dengan pengukuran menggunakan output oriented.

Tabel 1. Hasil pengolahan data pendekatan intermediasi

\begin{tabular}{llllll}
\hline Tahun & BAZNAS & CRS (\%) & VRS (\%) & $\begin{array}{c}\text { Scale } \\
(\%)\end{array}$ & RTS \\
\hline
\end{tabular}




\begin{tabular}{|c|c|c|c|c|c|}
\hline \multirow[t]{4}{*}{2015} & Kota Bogor & 94.6 & 100 & 94.6 & IRS \\
\hline & Kab Bogor & 100 & 100 & 100 & - \\
\hline & $\mathrm{Kab}$ & 100 & 100 & 100 & - \\
\hline & Sukabumi & & & & \\
\hline \multirow[t]{5}{*}{2016} & Kota Bogor & 50.3 & 100 & 50.3 & IRS \\
\hline & Kab Bogor & 44.6 & 100 & 44.6 & IRS \\
\hline & $\mathrm{Kab}$ & 100 & 100 & 100 & - \\
\hline & Sukabumi & & & & \\
\hline & Rata-rata & 81.6 & 100 & 81.6 & \\
\hline
\end{tabular}

Hasil pengolahan data pada tabel 1 menunjukkan, terjadi penurunan nilai efisiensi teknis dengan asumsi CRS pada BAZNAS Kota dan Kabupaten Bogor, sedangkan BAZNAS Kabupaten Sukabumi efisien 100 persen. Asumsi VRS menghasilkan nilai efisiensi 100 persen pada semua BAZNAS yang diteliti. Efisiensi skala merupakan perbandingan antara skor efisiensi CRS dan VRS, karena asumsi VRS efisien 100 persen sehingga nilai efisiensi skala sama dengan asumsi CRS. Metode DEA juga mengukur seberapa optimal penggunaan input dalam menghasilkan output. Lembaga akan memiliki salah satu dari kondisi Return To Scale (RTS), yaitu Increasing Return to Scale (IRS) dan Decreasing Return to Scale (DRS). Pada pendekatan intermediasi terjadi IRS pada BAZNAS Kota dan Kabupaten Bogor.

Nilai efisiensi BAZNAS Kota Bogor menurun dari 94.6 persen menjadi 50.3 persen dengan asumsi CRS. Sementara dengan asumsi VRS BAZNAS Kota Bogor efisien 100 persen. Penurunan skor efisiensi disebaban oleh berkurangnya persentase penyaluran dana terhimpun oleh BAZNAS Kota Bogor. Penyebab berkurangnya persentase penyaluran adalah beberapa program sementara dihentikan akibat adanya pergantian kepengurusan BAZNAS Kota Bogor pada akhir tahun 2016. Penyaluran dana zakat yang terkumpul dilanjutkan setelah pengurus baru terpilih pada awal tahun 2017.

Pada tahun 2015 dan 2016 BAZNAS Kabupaten Bogor memperoleh skor efisiensi 100 persen dengan asumsi VRS. Asumsi CRS menghasilkan skor efisiensi 100 persen pada tahun 2015. Skor efisiensi menunjukkan bahwa kinerja BAZNAS Kabupaten Bogor telah efisien dalam menyalurkan dana zakat. Akan tetapi, terjadi penurunan skor efisiensi yang besar pada tahun 2016 dengan asumsi CRS. Penurunan nilai efisiensi pada asumsi CRS disebabkan oleh penurunan persentase penyaluran dana zakat. Penurunan penyaluran dana zakat disebabkan oleh penyesuaian dengan Rancangan Kegiatan Awal Tahun (RKAT).

Badan Amil Zakat Kabupaten Sukabumi memperoleh skor efisiensi 100 persen dengan asumsi CRS dan VRS. Hal ini menunjukkan bahwa kinerja BAZNAS Kabupaten Sukabumi dalam menyalurkan dana zakat telah efisien. Selain itu, BAZNAS Kabupaten Sukabumi merupakan acuan bagi BAZNAS Kota dan Kabupaten Bogor dalam mengoptimalkan nilai efisiensinya. Apabila dibandingkan dengan BAZNAS lain yang diteliti, 
BAZNAS Kabupaten Sukabumi merupakan BAZNAS yang kinerjanya paling efisien dalam menyalurkan dana zakat.

Variable return to scale mengasumsikan setiap penambahan input dapat menghasilkan output yang lebih besar atau lebih kecil. Hasil perhitungan dengan VRS semua BAZNAS memperoleh skor efisiensi sebesar 100 persen. Hal tersebut disebabkan perhitungan VRS dipengaruhi juga oleh faktor eksternal diluar variabel yang digunakan. Menurut Akbar (2009) tingginya nilai efisiensi teknis VRS dibandingkan dengan efisiensi skala menunjukkan bahwa kinerja BAZNAS telah baik. Kinerja BAZNAS dalam menghimpun dan menyalurkan dana zakat telah baik. Akan tetapi, kurang mendapat dukungan dari kondisi eksternal (luar manajemen).

Hasil perhitungan menunjukkan adanya kondisi Increasing Return to Scale (IRS). Badan Amil Zakat Kota Bogor selama dua tahun mengalami increasing return to scale. Badan Amil Zakat Kabupaten Bogor mengalami increasing return to scale pada tahun 2016. Kondisi IRS disebabkan penggunaan input yang belum optimal. OutputDMU dapat terus ditingkatkan dengan mempertahankan input. Penambahan input tidak efektif karena sumber daya yang digunakan belum optimal.

\section{b. Pendekatan Produksi}

Pendekatan produksi yaitu pendekatan yang mengasumsikan BAZNAS sebagai penghasil dana terhimpun dan dana tersalurkan. Fokus pendekatan ini adalah berapa banyak biaya yang dikeluarkan dalam menghimpun dan menyalurkan dana zakat. Model yang digunakan yaitu Constant Return to Scale (CRS) dan Variabel Return to Scale (VRS). Pengukuran menggunakan input oriented. Variabel input yang digunakan dalam penelitian ini adalah biaya operasional dan biaya sosialisasi. Variabel output yang digunakan yaitu dana terhimpun dan dana tersalurkan. Setiap BAZNAS mengambil hak amilin untuk biaya operasional tidak lebih dari 12.5 persen. Besarnya biaya operasional yang melebihi bagian amilin diperoleh dari dana hibah. Pada tahun 2015 semua BAZNAS memperoleh dana hibah, sedangkan pada tahun 2016 BAZNAS Kabupaten Sukabumi tidak memperoleh dana hibah. Berikut adalah hasil olahan data dari BAZNAS Kota Kabupaten Bogor dan Kabupaten Sukabumi:

Tabel 2. Hasil pengolahan data pendekatan produksi

\begin{tabular}{|c|c|c|c|c|c|}
\hline Tahun & BAZNAS & $\begin{array}{l}\text { CRS } \\
(\%)\end{array}$ & VRS (\%) & $\begin{array}{c}\text { Scale } \\
(\%)\end{array}$ & RTS \\
\hline \multirow[t]{3}{*}{2015} & Kota Bogor & 32.9 & 57.3 & 57.4 & IRS \\
\hline & Kab Bogor & 77.3 & 100 & 77.3 & IRS \\
\hline & $\begin{array}{l}\text { Kab } \\
\text { Sukabumi }\end{array}$ & 100 & 100 & 100 & - \\
\hline \multirow[t]{4}{*}{2016} & Kota Bogor & 45.0 & 74.4 & 60.4 & IRS \\
\hline & Kab Bogor & 100 & 100 & 100 & - \\
\hline & $\begin{array}{l}\text { Kab } \\
\text { Sukabumi }\end{array}$ & 100 & 100 & 100 & - \\
\hline & Rata-rata & 71.7 & 90.9 & 76.5 & \\
\hline
\end{tabular}


Tabel 2 menunjukkan hasil pengolahan data menggunakan pendekatan produksi dengan asumsi CRS dan VRS. Badan Amil Zakat Nasional Kabupaten Sukabumi mengalami efisiensi 100 persen dengan asumsi CRS dan VRS. Badan Amil Zakat Nasional Kota Bogor mengalami peningkatan efisiensi pada kedua asumsi, akan tetapi belum mencapai 100 persen. Badan Amil Zakat Nasional Kabupaten Bogor efisien pada pengukuran dengan asumsi VRS, dan mengalami peningkatan skor efisiensi pada asumsi CRS.

Hasil dari perhitungan dengan asumsi CRS dan pengukuran berorientasi input menunjukkan, nilai efisiensi BAZNAS Kota Bogor relatif kecil hanya 32.9 persen pada tahun 2015. Pada tahun 2016 nilai efisiensi mengalami peningkatan menjadi 45.5 persen. Pada asumsi VRS skor efisiensi teknis BAZNAS lebih besar. Akan tetapi, skor efisiensi yang diperoleh belum mencapai 100 persen. Jika dibandingkan dengan kedua BAZNAS lainnya BAZNAS kota Bogor memiliki nilai efisiensi yang paling kecil. Hal tersebut disebabkan oleh besarnya persentase biaya operasional dan biaya sosialisasi BAZNAS Kota Bogor.

Nilai efisiensi BAZNAS Kabupaten Bogor dengan asumsi CRS mengalami peningkatan. Pada tahun 2015 diperoleh skor efisiensi sebesar 77.3 persen, sedangkan pada tahun 2016 sebesar 100 persen. Skor yang diperoleh menunjukkan terdapat perbedaan antara asumsi CRS dan asumsi VRS. Asumsi CRS menghasilkan skor efisiensi teknis yang efisien di tahun 2016. Asumsi VRS menghasilkan skor efisien teknis yang efisien 100 persen di tahun 2015 dan 2016.

Badan Amil Zakat Nasional Kabupaten Sukabumi memperoleh skor efisiensi teknis sebesar 100 persen. Persentase biaya operasional dan sosialisasi BAZNAS Kabupaten Sukabumi relatif kecil, dibandingkan dana zakat yang terhimpun dan tersalurkan. Kebijakan Bupati menyebabkan dana terhimpun lebih besar tanpa membutuhkan biaya sosialisasi yang besar. Badan Amil Zakat Nasional Kabupaten Sukabumi menghasilkan skor efisiensi 100 persen pada pendekatan intermediasi dan produksi.

Badan Amil Zakat Nasional Kota dan Kabupaten Bogor mengalami increasing return to scale pada tahun 2015. Pada tahun 2016 hanya BAZNAS Kota Bogor yang mengalami kondisi IRS. Kodisi ini disebabkan belum optimalnya penggunaan input oleh kedua BAZNAS tersebut. Badan Amil Zakat Kota dan Kabupaten Bogor masih dapat meningkatkan outputnya. Badan Amil Zakat Nasional Kabupaten Sukabumi merupakan acuan bagi BAZNAS Kota Bogor dan Kabupaten Bogor untuk memaksimalkan nilai efisiensinya.

\subsection{ANALISIS PENYEBAB INEFISIENSI DAN REKOMENDASI MENINGKATKAN EFISIENSI}

a. Pendekatan Intermediasi

Pendekatan intermediasi menunjukkan hanya BAZNAS Kabupaten Sukabumi yang efisien selama dua tahun. Badan Amil Zakat Kota Bogor 
mengalami penurunan efisiensi dengan asumsi CRS. Badan Amil Zakat Kabupaten Bogor efisien pada tahun 2015, dan mengalami penurunan pada tahun 2016 dengan asumsi CRS. Berikut adalah sumber inefiensi pendekatan intermediasi dan target yang diperoleh metode DEA.

Tabel 3. Sumber inefisiensi dan target pendekatan intermediasi (CRS)

\begin{tabular}{cclc}
\hline Tahun & BAZNAS & \multicolumn{1}{c}{ Sumber } & Target $(\%)$ \\
\hline \multirow{2}{*}{2015} & Kota Bogor & Biaya operasional & -54.9 \\
\cline { 3 - 4 } & & Dana tersalurkan & 5.7 \\
\hline \multirow{2}{*}{2016} & \multirow{2}{*}{ Kota Bogor } & Biaya operasional & -55.0 \\
\cline { 3 - 4 } & & Dana tersalurkan & 98.8 \\
\cline { 3 - 4 } & \multirow{2}{*}{ Kab Bogor } & Biaya operasional & -24.9 \\
\cline { 3 - 4 } & & Dana tersalurkan & 124.3 \\
\hline
\end{tabular}

Sumber: Hasil pengolahan software DEAP Version 2.1 (diolah)

Tabel 3 menunjukkan bahwa penyebab inefisiensi dalam pendekatan intermediasi adalah biaya operasional dan dana tersalurkan. Target merupakan persentase yang harus dicapai agar lembaga efisien. Pada asumsi CRS, BAZNAS Kota Bogor mengalami inefisiensi selama dua tahun, dan BAZNAS Kabupaten Bogor inefisien pada tahun 2016. Pada asumsi VRS semua BAZNAS memperoleh skor efisiensi 100 persen, sehingga tidak ada variabel yang menyebabkan inefisiensi.

Badan Amil Zakat Nasional Kota Bogor mengalami inefisensi di tahun 2015 dan 2016. Usaha yang dapat dilakukan oleh BAZNAS Kota Bogor agar dapat efisien adalah dengan meningkatkan dana tersalurkan dan mengurangi biaya operasional. Pada tahun 2015, biaya operasional BAZNAS Kota Bogor harus dikurangi 54.9 persen agar BAZNAS dapat efisien. Dana yang disalurkan BAZNAS Kota Bogor di tahun 2015 harus ditingkatkan sebesar 5.7 persen. Pada tahun 2016, biaya operasional BAZNAS Kota Bogor harus dikurangi 55 persen agar dapat mencapai nilai efisiensi 100 persen. Dana tersalurkan ditahun 2016 harus ditingkatkan sebesar 98.8 persen.

Badan Amil Zakat Nasional Kabupaten Bogor mengalami inefisiensi di tahun 2016. Usaha yang dapat dilakukan agar efisien adalah mengurangi biaya operasional dan meningkatkan dana tersalurkan. Pada tahun 2016, BAZNAS Kabupaten Bogor harus mengurangi biaya operasional sebesar 24.9 persen, agar BAZNAS Kabupaten Bogor dapat memperoleh nilai efisiensi 100 persen. Dana yang tersalurkan oleh BAZNAS Kabupaten Bogor ditahun 2016 harus ditingkatkan sebesar 124.3 persen.

\section{b. Pendekatan Produksi}

Pengukuran efisiensi dalam penelitian ini, juga menggunakan pendekatan produksi. Asumsi yang digunakan yaitu asumsi CRS dan VRS yang pengukurannya berorientasi input. Berikut adalah sumber inefisiensi dan target yang harus dicapai oleh BAZNAS yang belum efisien.

Tabel 4. Sumber inefisiensi dan target pendekatan produksi (CRS)

Biaya Biaya Dana Dana




\begin{tabular}{clcccc}
\hline Tahun & BAZNAS & $\begin{array}{c}\text { operasional } \\
(\%)\end{array}$ & $\begin{array}{c}\text { sosialisasi } \\
(\%)\end{array}$ & $\begin{array}{c}\text { terhimpun } \\
(\%)\end{array}$ & $\begin{array}{c}\text { tersalurkan } \\
(\%)\end{array}$ \\
\hline 2015 & $\begin{array}{l}\text { Kota } \\
\text { Bogor }\end{array}$ & -67.0 & -96.6 & 0.8 & - \\
\cline { 2 - 6 } & $\begin{array}{l}\text { Kab } \\
\text { Bogor }\end{array}$ & -22.7 & -94.2 & 6.6 & - \\
\hline 2016 & $\begin{array}{l}\text { Kota } \\
\text { Bogor }\end{array}$ & -55.0 & -93.6 & - & 98.8 \\
\hline
\end{tabular}

Sumber: Hasil pengolahan software DEAP Version 2.1 (diolah)

Tabel 4 menunjukkan penyebab inefisiensi pada pendekatan produksi dengan asumsi CRS. Hasil perhitungan di tabel 2 menunjukkan, hanya BAZNAS Kabupaten Sukabumi yang efisien pada pendekatan produksi dengan asumsi CRS dan VRS. Oleh sebab itu, hanya BAZNAS Kota dan Kabupaten Bogor yang dianalisis penyebab inefisiensinya. Pada tahun 2015 penyebab inefisiensi pada BAZNAS Kota dan Kabupaten Bogor adalah biaya operasional, biaya sosialisasi, dan dana terhimpun. Pada tahun 2016 penyebab inefisiensi pada BAZNAS Kota Bogor adalah biaya operasional, biaya sosialisasi, dan dana tersalurkan.

Hasil perhitungan menggunakan pendekatan produksi dengan asumsi CRS, BAZNAS Kota Bogor belum efisien pada tahun 2015 dan 2016. Pada tahun 2015, usaha yang dapat dilakukan BAZNAS Kota Bogor agar efisien yaitu harus mengurangi biaya operasional, biaya sosialisasi, dan meningkatkan dana terhimpun. Biaya operasional BAZNAS Kota Bogor pada tahun 2015 harus dikurangi sebesar 67.0 persen. Biaya sosialisasi BAZNAS Kota Bogor tahun 2015 berdasarkan perhitungan DEA harus dikurangi 96.6 persen. Dana terhimpun BAZNAS Kota Bogor tahun 2015 harus ditingkatkan 0.8 persen. Pada tahun 2016, agar efisien BAZNAS Kota Bogor harus mengurangi biaya operasional, biaya sosialisasi, dan meningkatkan dana tersalurkan. Biaya operasional yang dikeluarkan BAZNAS Kota Bogor pada tahun 2016 harus dikurangi sebesar 55.0 persen agar efisien. Biaya sosialisasi yang dikeluarkan BAZNAS Kota Bogor di tahun 2016 harus dikurangi sebesar 93.6 persen. Dana yang disalurkan BAZNAS Kota Bogor di tahun 2016 harus ditingkatkan 98.8 persen agar dapat efisien.

Hasil perhitungan menggunakan pendekatan produksi dengan pengukuran berorientasi input, BAZNAS Kabupaten Bogor mengalami inefisiensi di tahun 2015. Berdasarkan perhitungan DEA penyebab inefisiensi adalah biaya operasional, biaya sosialisasi, dan dana terhimpun. Pada tahun 2015, usaha yang dapat dilakukan agar efisien BAZNAS Kabupaten Bogor harus mengurangi biaya operasional, biaya sosialisasi, dan meningkatkan dana terhimpun. Biaya operasional yang dikeluarkan BAZNAS Kabupaten Bogor harus dikurangi sebesar 22.7 persen. Biaya sosialiasi yang dikeluarkan BAZNAS Kabupaten Bogor di tahun 2015 harus dikurangi 94.2 persen agar dapat efisien. Dana zakat yang dihimpun BAZNAS Kabupaten Bogor di tahun 2015 harus ditingkatkan sebesar 6.6 persen. 
Pengukuran efisiensi menggunakan pendekatan produksi dengan asumsi VRS, menghasilkan inefisiensi pada BAZNAS Kota Bogor. Inefisiensi pada BAZNAS Kota Bogor terjadi di tahun 2015 dan 2016. Badan Amil Zakat Nasional Kabupaten Bogor dan Kabupaten Sukabumi telah efisien dengan asumsi VRS. Berikut adalah sumber inefisiensi dan target yang harus dicapai oleh BAZNAS Kota Bogor.

Tabel 5. Sumber inefisiensi dan target pendekatan produksi (VRS)

\begin{tabular}{clcccc}
\hline Tahun & BAZNAS & $\begin{array}{c}\text { Biaya } \\
\text { operasional } \\
(\%)\end{array}$ & $\begin{array}{c}\text { Biaya } \\
\text { sosialisasi } \\
(\%)\end{array}$ & $\begin{array}{c}\text { Dana } \\
\text { terhimpun } \\
(\%)\end{array}$ & $\begin{array}{c}\text { Dana } \\
\text { tersalurkan } \\
(\%)\end{array}$ \\
\hline 2015 & $\begin{array}{l}\text { Kota } \\
\text { Bogor }\end{array}$ & -42.6 & -42.6 & 41.8 & 46.5 \\
\hline 2016 & $\begin{array}{l}\text { Kota } \\
\text { Bogor }\end{array}$ & -25.6 & -93.1 & 24.3 & 10.1 \\
\hline
\end{tabular}

Sumber: Hasil pengolahan software DEAP Version 2.1 (diolah)

Tabel 5 menunjukkan sumber inefisiensi dan target yang perlu dicapai agar BAZNAS Kota Bogor dapat efisien. Inefisiensi selama dua tahun disebabkan oleh biaya operasional, biaya sosialisasi, dana terhimpun, dan dana tersalurkan. Berdasarkan perhitungan metode DEA, usaha yang dapat dilakukan BAZNAS Kota Bogor agar dapat efisien adalah dengan mengurangi biaya operasional dan biaya sosialisasi, serta meningkatkan penghimpunan dan penyaluran dana zakat.

Biaya operasional yang dikeluarkan BAZNAS Kota Bogor pada 2015 harus dikurangi 42.6 persen. Biaya sosialisasi yang dikeluarkan BAZNAS Kota Bogor pada tahun 2015 harus dikurangi 42.6 persen agar BAZNAS Kota Bogor dapat efisien. Dana yang dihimpun BAZNAS Kota Bogor tahun 2015 harus ditingkatkan sebesar 41.8 persen. Dana yang disalurkan BAZNAS Kota Bogor di tahun 2015 harus ditingkatkan sebesar 46.5 persen.

Pada tahun 2016, penyebab inefisiensi pada BAZNAS Kota Bogor yaitu biaya operasional, biaya sosialisasi, dana terhimpun, dan dana tersalurkan. Usaha yang dapat dilakukan BAZNAS Kota Bogor agar efisien adalah mengurangi biaya operasional dan biaya sosialisasi, serta meningkatkan dana terhimpun dan dana tersalurkan. Biaya operasional yang dikeluarkan harus dikurangi 25.6 persen. Biaya sosialisasi yang dikeluarkan BAZNAS Kota Bogor pada tahun 2016 harus dikurangi 93.1 persen agar BAZNAS Kota Bogor dapat efisien. Dana zakat yang dihimpun BAZNAS Kota Bogor harus ditingkatkan sebesar 24.3 persen. Dana yang disalurkan BAZNAS Kota Bogor di tahun 2016 harus ditingkatkan sebesar 10.1 persen agar BAZNAS Kota Bogor memperoleh nilai efisiensi 100 persen.

\section{SIMPULAN}

Mengukur efisiensi kinerja BAZNAS Kota dan Kabupaten Bogor, serta Kabupaten Sukabumi menggunakan metode DEA. Pendekatan yang 
digunakan dalam DEA, yaitu pendekatan intermediasi dan pendekatan produksi. Hasil perhitungan efisiensi dengan pendekatan intermediasi menunjukkan semua BAZNAS efisien dengan asumsi VRS. Badan Amil Zakat Nasional Kota Bogor mengalami penurunan skor efisiensi pada asumsi CRS. Badan Amil Zakat Nasional Kabupaten Bogor efisien pada tahun 2015, dan mengalami penurunan nilai efisiensi di tahun 2016 dengan asumsi CRS. Badan Amil Zakat Nasional Kabupaten Sukabumi efisien 100 persen dengan asumsi CRS dan VRS. Badan Amil Zakat Nasional Kota dan Kabupaten Bogor mengalami kondisi increasing return to scale.

Hasil perhitungan dengan pendekatan produksi menunjukkan Badan Amil Zakat Nasional Kota Bogor mengalami peningkatan efisiensi, akan tetapi belum mencapai 100 persen. Badan Amil Zakat Nasional Kabupaten Bogor efisien pada asumsi VRS dan mengalami peningkatan nilai efisiensi pada asumsi CRS. Badan Amil Zakat Nasional Kabupaten Sukabumi efisien pada asumsi CRS dan VRS. Badan Amil Zakat Nasional Kota dan Kabupaten mengalami kondisi IRS.

Usaha yang dapat dilakukan untuk meningkatkan nilai efisiensi BAZNAS yang belum efisien didasarkan pada penyebab inefisiensi lembaga. Pada pendekatan intermediasi penyebab inefisiensi yaitu biaya operasional dan dana tersalurkan. Oleh sebab itu, lembaga yang belum efisien yaitu BAZNAS Kota Bogor dan Kabupaten Bogor perlu mengurangi biaya operasional dan meningkatkan dana tersalurkan. Pendekatan produksi menunjukkan penyebab inefisensi adalah semua variabel. Badan Amil Zakat Nasional yang belum efisien yaitu BAZNAS Kota dan Kabupaten Bogor perlu mengurangi biaya operasional dan biaya sosialisasi, serta meningkatkan dana terhimpun dan dana tersalurkan.

\section{DAFTAR PUSATAKA}

Akbar, N. (2009). Analisis Efisiensi Organisasi Pengelola Zakat Nasional dengan Pendekatan Data Envelopment Analysis. Islamic Finance and Business Review, 4(2), 760-784.

Al-Parisi, S. (2017). Tingkat Efisiensi dan Produktivitas Lembaga Zakat di Indonesia. Jurnal Bisnis dan Manajemen, 7(1), 63-72.

Beik, I. S. (2009). Analisis peran zakat dalam mengurangi kemiskinan: studi kasus Dompet Dhuafa Republika. Jurnal Zakat \& Empowering, 2, 47 55.

Cahyono, F E. (2015). Efficiency of BAZNAS (Indonesia National Zakat Amil Agency) Performance. Proceedings of Sydney International Business Research Conference 2015 (pp. 301-318). Australia: University of Western Sydney Campbelltown. 
Coelli, TJ., Rao, DSP., O’Donell, CJ., \& Battese, GE. (2005). An Introduction to Efficiency and Productivity Analysis. New York: Springer.

Hafidhuddin, D. (2002). Zakat Dalam Perekonomian Modern. Jakarta: Gema Insani.

KSP. (2016). Potensi Zakat di Indonesia Sangat Besar. Retrieved April 20, 2017, from http://ksp.go.id.

Lestari, A. (2015). Efisiensi Kinerja Keuangan Badan Amil Zakat Daerah (BAZDA): Pendekatan Data Envelopment Analysis (DEA). Jurnal Ekonomi dan Studi Pembangunan, 16(2), 177-187.

PUSKASBAZNAS. (2016). Outlook Zakat Indonesia 2017. Jakarta: Pusat Kajian Strategis Badan Amil Zakat Nasional.

Qardawi, Y. (2011). Hukum Zakat. Jakarta: Litera Antarnusa.

Rahmayanti, A. (2014). Efisiensi Lembaga Amil Zakat dalam Mengelola Zakat di Indonesia (Studi Kasus: PKPU, Rumah Zakat, dan BAMUIS BNI)(Thesis). Retrieved from http://repository.uinjkt.ac.id

Rusydiana, A.S., \& Al-Farisi, S. (2016). The Efficiency of Zakah Institutions Using Data Envelopment Analysis. Jurnal Ilmu Ekonomi Syariah, $8(2), 213-226$.

Santika, Y. (2015). Analisis Potensi Zakat dan Faktor-faktor yang Memengaruhi Muzaki Membayar Zakat di Kota Bogor (Thesis). Retrieved from http://repository.ipb.ac.id. 